\title{
Sistem Informasi Pengajuan Klaim Asuransi Kendaraan Berbasis Web Menggunakan UML
}

\author{
Anton Sujarwo ${ }^{1}$, Adika May Sari ${ }^{1}$, Rina Lestari ${ }^{2}$, Desri Yani $^{3}$ \\ ${ }^{1}$ Teknologi Industri, Sistem Informasi, Universitas BSI, DKI Jakarta, Indonesia \\ ${ }^{2}$ Komunikasi dan Bahasa, Bahasa Inggris, Universitas BSI, DKI Jakarta, Indonesia \\ ${ }^{3}$ Teknologi Industri, Sistem Informasi, Universitas BSI, DKI Jakarta, Indonesia \\ Email: ${ }^{1}$ anton@bsi.ac.id, ${ }^{2}$ adika.dik@bsi.ac.id, ${ }^{3}$ rina.rls@bsi.ac.id, ${ }^{4}$ desriyani.dsr@bsi.ac.id
}

\begin{abstract}
Abstrak-Perkembangan teknologi dan informasi sangat membantu dalam sebuah organisasi. Organisasi di perusahaan yaitu PT. Assuransi Chubb Syariah Indonesia dalam sistem informasi Pengajuan Klaim Kendaraan masih menggunakan sistem manual atau belum terkomputerisasi, hal tersebut menimbulkan kurangnya informasi Pengajuan Klaim Kendaraan yang efektif dan efisien. Sehingga dibutuhkannya sistem informasi Pengajuan Klaim Kendaraan yang efektif dan efisien dengan terkomputerisasinya sebuah sistem menggunakan berbasis website, untuk membantu memperlancar pengelolaan informasi Pengajuan Klaim Kendaraan.Untuk mengembangkan sistem informasi Pengajuan Klaim Kendaraan yang menggunakan metode waterfall. Hasil pengujian menunjukan bahwa sistem informasi mampun melakukan proses Pengajuan Klaim Kendaraan secara online dapat efektif dan efisien.
\end{abstract}

Kata Kunci: Sistem Informasi, Pengajuan Klaim Kendaraan, UML

\begin{abstract}
The development of technology and information is very helpful in an organization. Organizations in the company, namely PT. Chubb Syariah Indonesia insurance in the Vehicle Claim Filing information system is still using manual systems or has not been computerized, this results in a lack of effective and efficient Vehicle Claim Submission information. So the need for an effective and efficient Vehicle Claim Submission information system with a computerized website-based system, to help expedite the management of Vehicle Claim Submission information. To develop a Vehicle Claim Submission information system that uses the waterfall method. The test results show that the information system is able to make the process of filing a Vehicle Claim online can be effective and efficient.
\end{abstract}

Keywords: Information Systems, Submitting Vehicle Claims, UML

\section{PENDAHULUAN}

Dengan seiring meningkatnya jumlah produksi kendaraan bermotor pada setiap tahunya, membuat berbagai macam perusahaan jasa jaminan semakin banyak berdiri khususnya perusahaan asuransi kendaraan yang memberikan jaminan atau tanggungan terhadap suatu asset (kendaraan), dengan maksud mengantisipasi segala kerugian (Loss) terhadap segala bentuk kejadian. Sistem proses klaim asuransi kendaraan bermotor yang tersedia saat ini umumnya hanya berfungsi untuk mempermudah nasabah dalam pengajuan klaim. Sedangkan kenyamanan dan kemudahan nasabah dalam hal proses klaim asuransi kendaraan bermotor sangatlah penting. (Kirana, Perkasa, \& Saputra, 2018)

Asuransi kesehatan komersial (Shasta) di Indonesia telah ada sejak tahun 1970, namun perkembangannya sangat lambat sampai tahun 1992 karena landasan hukum yang tidak jelas (Thabrany, 2014). Pada saat itu, asuransi kesehatan dijual sebagai produk tumpangan (rider) oleh perusahaan asuransi kerugian. Sedangkan perusahaan asuransi jiwa tidak jelas dapat menjual atau tidak produk tersebut. Dengan dikeluarkannya UU Nomor 2 tahun 1992 tentang asuransi, maka baik asuransi kerugian maupun asuransi jiwa boleh menjual produk asuransi kesehatan.(Sari, 2016)

Sulitnya proses pengajuan klaim yang belum didukung oleh sebuah sistem seringkali menjadi masalah tersendiri bagi para pemegang polis asuransi. Semuanya ada didalam kesepakatan anatara pihak terkait dengan pembeli polis asuransi. Sebagai jalan keluar dan soslusi masalah di atas penulisan ini bermaksud merancang sebuah situs layanan berbasis web yang dapat diakses melalui laptop atau perangkat-perangkat lainya dengan cara yang sudah sangat umum dan mudah, sehingga dapat mebantu nasabah dalam proses pengajuan klaim lebih efektif dan efesien.

Adapun tujuan penelitian, yaitu merancang dan membangun sebuah perancangan sistem informasi pengajuan klaim kendaraan untuk meningkatkan efektifitas dan efisiensi baik dalam monitoring maupun pelayanan informasi. Agar pelayanan Sistem Informasi pengajuan klaim kendaraan menjadi salah satu jalan keluar untuk pengguna jasa jaminan asuransi dan secara keseluruhan dapat mudah di akses dengan berbagai perangkat secara mudah kapanpun dan dimanapun.

Batasan penelitian dalam system informasi ini meliputi proses pengajuan klaim dimana terdapat beberapa form yaitu Membuat sistem mulai dari masukan (Input) berupa pengolahan formulir pengajuan formulir klaim (Form Claim), dan pengolahan laporan sekaligus melihat claim progres, kemudian memproses data tersebut menjadi data keluaran (Output) berupa laporan.

Kajian pustaka yang digunakan sebagai pembanding yaitu Adi Supriyatna 2016 tentang Sistem Informasi Pengajuan Klaim Jaminan Pemeliharaan Kesehatan Berbasis Web, dimana aplikasi ini berisi tentang system informasi berbasis web untuk pengajuan klaim asuransi kesehatan. 


\section{METODE PENELITIAN}

Dalam penelitian ini, penulis menggunakan metode waterfall, di mana metode waterfall atau sering disebut dengan model sekuensial linier menyediakan pendekatan alur hidup suatu perangkat lunak secara sekuensial atau terurut yang dimulai dengan analisis, desain, pengkodean, pengujian, dan tahap pendukung. Tahapan di dalam metode waterfall adalah sebagai berikut:

\subsection{Metode Pengembangan Perangkat Lunak}

Pemodelan dalam suatu rekayasa perangkat lunak merupakan suatu hal yang dilakukan di tahapan awal. Dalam rekayasa perangkat lunak sebenarnya masih memungkinkan tanpa melakukan suatu pemodelan. Hal itu tidak dapat lagi dilakukan dalam suatu industri perangkat lunak karena dengan pemodelan maka akan lebih mudah untuk memahami sistem baik pengembang perangkat lunak itu sendiri maupun pelanggan. Dengan demikian pengembang akan lebih cepat dalam melakukan desain dan mengkontruksi program untuk perangkat lunak tersebut berdasarkan model yang sudah ada dan telah disepakati bersama. Pemodelan ini juga sering disebut dengan metodologi pengembangan sistem. (Pendidikan, Informatika, Teknik, \& Negeri, n.d.)

\section{Analisa kebutuhan}

Proses pengumpulan kebutuhan dilakukan secara intensif untuk menspesifikasikan kebutuhan perangkat lunak agar dapat dipahami perangkat lunak seperti apa yang di butuhkan oleh pengguna. Spesifikasi kebutuhan peranggkat lunak pada tahap ini perlu didokumentasikan.

\section{Perancangan Sistem dan Perangkat lunak}

Perancangan sistem pada penelitian ini, untuk memenuhi kebutuhan para pemakai atau user, serta memberikan gambaran dan rancangan terhadap system yang akan dibuat. Proses pengajuan klaim kendaraan bermotor akan jauh lebih mudah. Para nasabah hanya cukup mengakses web pada komputer maupun smartphone, dalam hal ini proses pengajuan klaim tidak perlu lagi datang secara langsung melakukan proses pengajuan klaim kendaraan bermotor secara konvensional.

\section{Implementasi dan Pengujian Unit.}

a. Implementasi.

Pada tahapan ini, dilakukan pengkodean terhadap desain sistem yang telah dirancang sebelumnya.

b. Pengujian Unit.

Pengujian yang digunakan pada penelitian ini untuk melihat fungsi dari keseluruhan sistem yang dibuat, menggunakan pengujian Blackbox

\subsection{Metode Pengumpulan Data}

1. Pengamatan Langsung (Observation)

Dalam metode ini, dilakukan pengamatan secara langsung pada kegiatan pengolaan data pengajuan klaim kendaraan yang masih manual pada Pt. Assuransi Chubb Syariah Indonesia

2. Metode Wawancara (Interview)

Metode ini dilakukan dengan cara mendatangi langsung tempat perusahaan Pt. Assuransi Chubb Syariah Indonesia yang telah penulis tunjuk sebagai objek, kemudian penulis melakukan tatap muka langsung dengan examiner klaim untuk mendapatkan data informasi lebih lengkap lagi.

3. Metode Studi Pustaka (Library)

Metode ini dilakukan dengan cara mengumpulkan data-data dan informasi yang diperlukan dengan mengkaji sumber pustaka dari buku-buku yang ada hubunganya dengan objek penelitian, dalam hal ini penulis memperoleh buku-buku sebagai referensi.

\subsection{Metode Pengembangan Sistem}

Menurut (Putri, Ayu, \& Wulandari, 2016) Model waterfall adalah "model SDLC (Software Development Life Cycle) yang paling sederhana. Model ini hanya cocok untuk pengembangan perangkat lunak dengan spesifikasi yang tidak berubah-ubah". Model SDLC air terjun (waterfall) sering juga disebut model sekuensial linier (sequential linear) atau alur hidup klasik (classic life cycle). Model air terjun menyediakan pendekatan alur hidup perangkat lunak secara sekuensial atau terurut. Dimulai dari analisis, desain, pengkodean, pengujian, dan tahap pendukung (support). (Shalahuddin \& Sukamto, 2018)

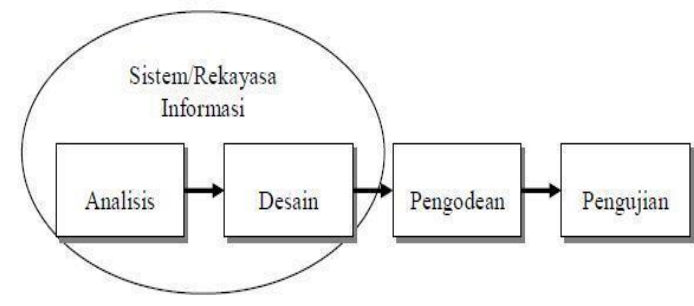

Gambar 1. Tahapan model air terjun 


\subsection{Unified Modelling Language (UML)}

Rekayasa Perangkat Lunak Menurut (Shalahuddin \& Sukamto, 2018) UML adalah satu standar bahasa yang banyak digunakan di dunia industri untuk mendefinisikan requirement, membuat analisis dan desain, sertamenggambarkan arsitektur dalam pemrograman berorientasi objek.

a. Use Case atau diagram use case merupakan pemodelan untuk kelakukan (behavior) sistem informasi yang akan dibuat. Use case mendeskripsikan sebuah interaksi antara satu atau lebih aktor dengan sistem informasi yang akan dbuat.

b. Class Diagram atau class diagram menggambarkan struktur sistem dari segi pendefinisian kelas-kelas yang kan dibuat untuk membangun sistem. Kelas memiliki atribut (variabel-variabel yang dimiliki suatu kelas) dan operasi atau metode (fungsi yang dimiliki suatu kelas).

c. Activity Diagram menggambarkan workflow (aliran kerja) atau aktivitas dari sebuah sistem atau proses bisnis atau menu yang ada pada perangkat lunak. Yang perlu diperhatikan disini adalah bahwa diagram aktivitas menggambarkan aktivitas sistem bukan apa yang dilakukan aktor, jadi aktivitas yang dilakukan oleh system.

d. Sequence Diagram menggambarkan kelakuan objek pada use case dengan mendeskripsikan waktu hidup objek dan message yang dikirim dan diterima antar objek.

\section{HASIL DAN PEMBAHASAN}

\subsection{Prosedur Sistem}

Prosedur sistem berjalan yang akan penulis jabarkan adalah langkah-langkah atau urutan sistem pengajuan klaim kendaraan pada PT Asuransi Chubb Syariah Indonesia. Berikut penjelasan dari urutan proses yang terjadi secara lebih terperinci antara lain :

\section{Pengisian Formulir Klaim}

Saat nasabah menghubungi call center dengan maksud ingin mengajukan klaim kendaraan, kemudian nasabah akan di mintai data dari polis asuransi dan persyaratan pendukung lainya serta wajib mencantumkan alamat email nasabah, kemudian nasabah diarahkan untuk mengisi formulir klaim sebagai syarat utama pengajuan klaim yang telah disampaikan melalui pesan email kepada tertanggung

\section{Prosedur Survey Kendaraan}

Setelah data pengajuan dinyatakan valid dan telah diproses oleh bagian klaim, selanjutnya dilakukan survei terhadap kendaraan, dimana penjadwalan survei disampaikan melalui telphone yang dilakukan oleh pihak surveor dengan mendatangi kendaraan tersebut dan melalukkan proses potret bagian kendaraan yang akan di klaim dan diperbaiki, kemudian setelah proses survei kendaraan, surveor memberikan laporan survei sebagai laporan untuk mengetahui bagian mana saja yang bisa tercover setelah proses pemotretan selesai.

\section{Prosedur Pemilihan Bengkel}

Selanjutnya setelah proses validasi data dan survei kendaraan selesai, nasabah diarahkan untuk memilih bengkel rekanan yang sudah tersedia di buku polis asuransi, setelah proses pemilihan bengkel selesai, pihak klaim langsung menginformasikan melalui sebuah sistem dan meminta estimasi biaya perbaikan kepada pihak bengkel yang bersangkutan, kemudian setelah estimasi selesai, pihak klaim segera membuat SPK dan mengkonfirmasi kepada nasabah untuk segera mengunjungi bengkel yang sudah ditetapkan sebelumnya.

\subsection{Analisis Kebutuhan}

Analisa Kebutuhan yang digunakan untuk mengidentifikasi kebutuhan yang diperoleh berdasarkan kebutuhan pengguna dan kebutuhan sistem.

1. Kebutuhan Pengguna

Dalam aplikasi sistem informasi pengajuan klaim kendaraan berbasis web terdapat dua pengguna yaitu: Admin dan Pengunjung. Kedua pengguna tersebut memiliki karakteristik interaksi dengan sistem yang berbeda-beda dan memiliki kebutuhan yang berbeda-beda, seperti berikut :

a. Skenario Kebutuhan Admin

1) Melakukan login.

2) Melihat menu utama (Homepage).

3) Dapat melihat data claim client.

4) Mengedit dan melihat data claim client.

5) Mengelola data claim dan memberikan keputusan.

6) Admin melakukan logout dari sistem.

b. Skenario Kebutuhan Client

1) Menampilkan menu utama (Hompage) Client.

2) Melihat data claim progres. 
3) Mengisi file claim register.

4) Client melakukan logout dari sistem.

\subsection{Entity Relationship Diagram (ERD)}

Pembuatan rancangan basis data untuk sistem informasi penjualan helm sepeda motor berbasis web ini dimulai dengan membuat Entity Relationship Diagram (ERD) dan kemudian dirubah menjadi Logical Record Structure (LRS). Perancangan basis data menghasilkan pemetaan tabel-tabel yang digambarkan dengan ERD

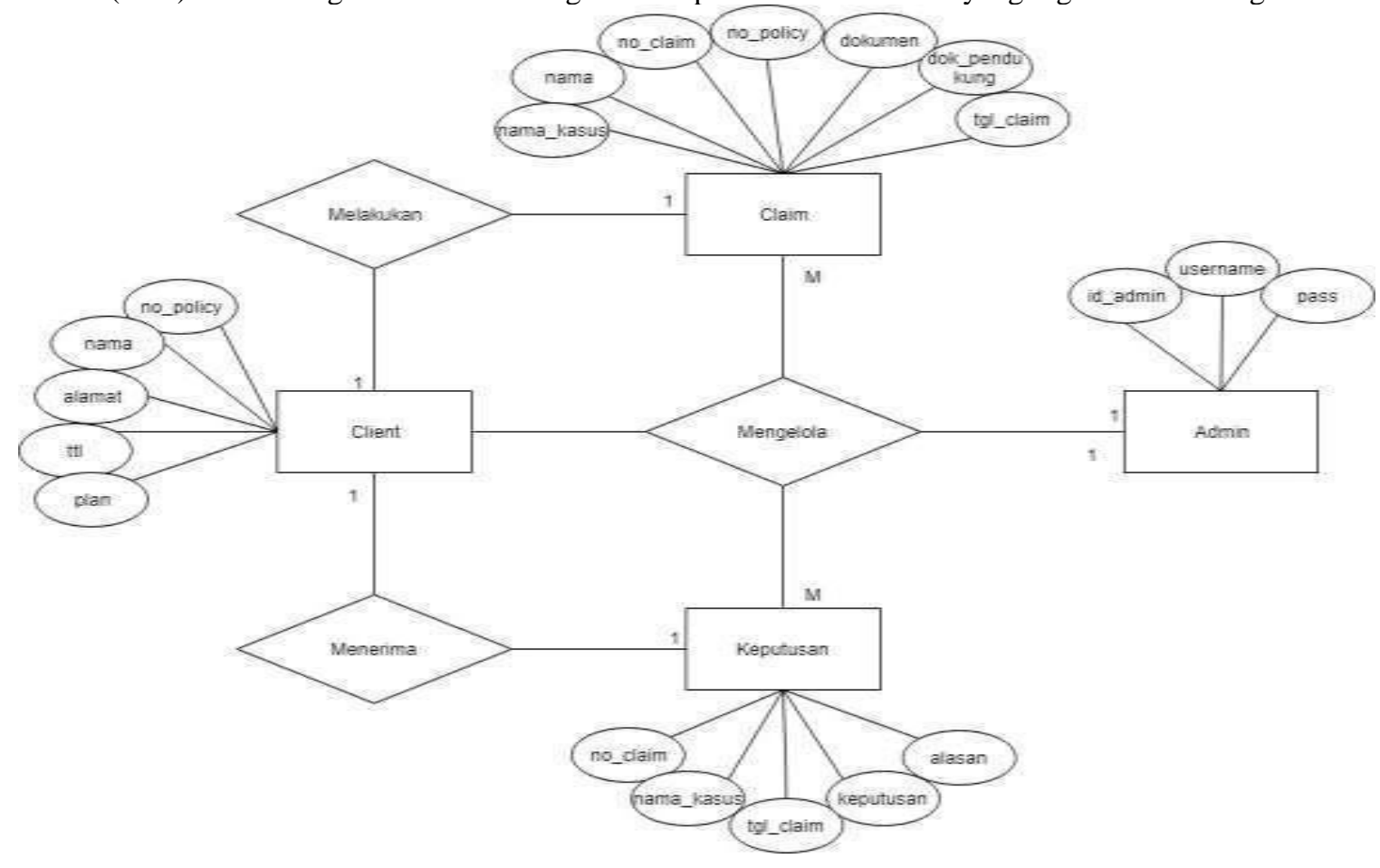

Gambar 2. Entity Relationship Diagram (ERD)

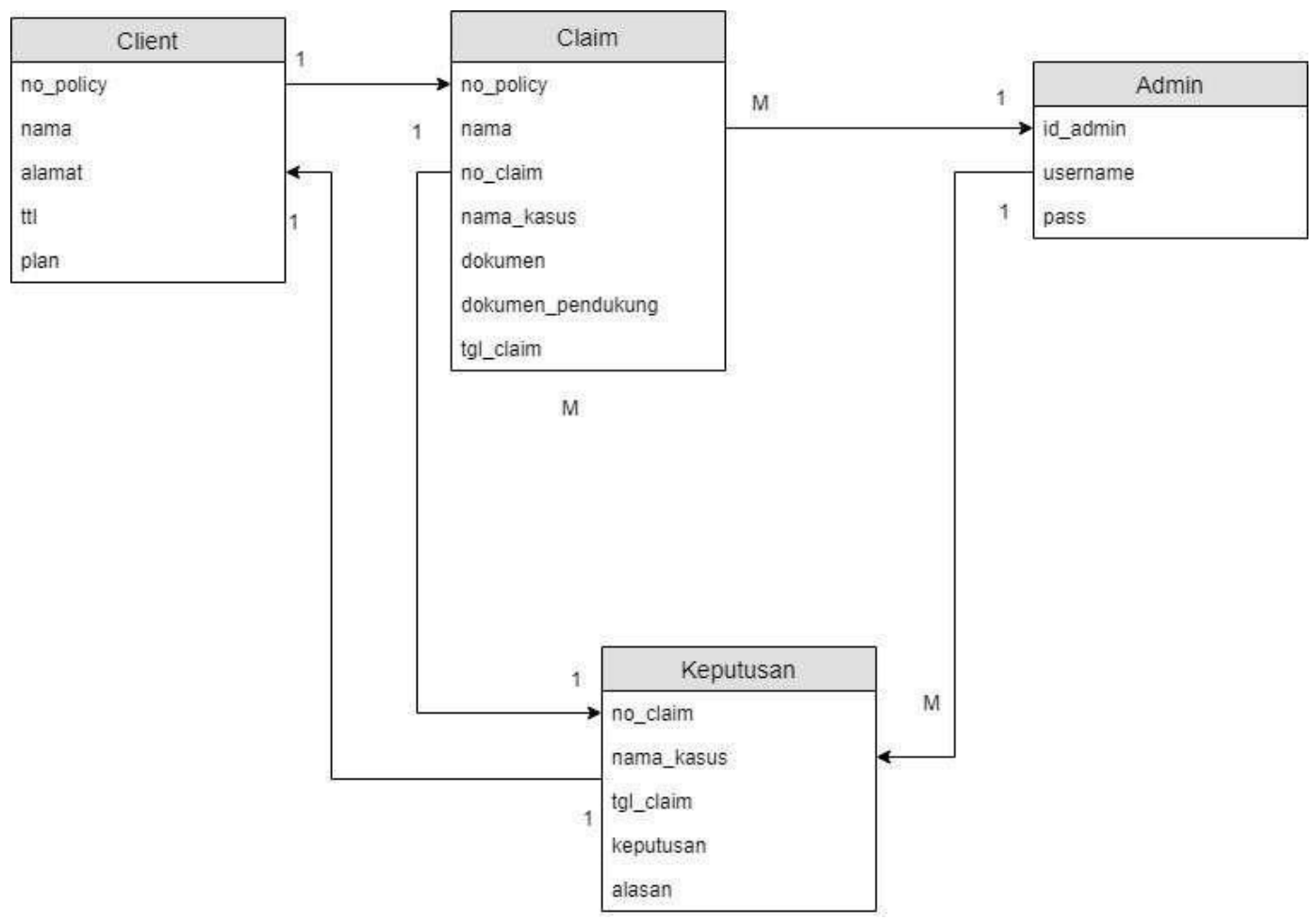

Gambar 3. Logical Record Structure

Anton Sujarwo, Copyright (C) 2020, Jurnal JSON, Page 297 


\subsection{Rancangan UML}

Diagram Use Case Sistem Informasi Pengajuan klaim PT. Assuransi Chubb Syariah Indonesia

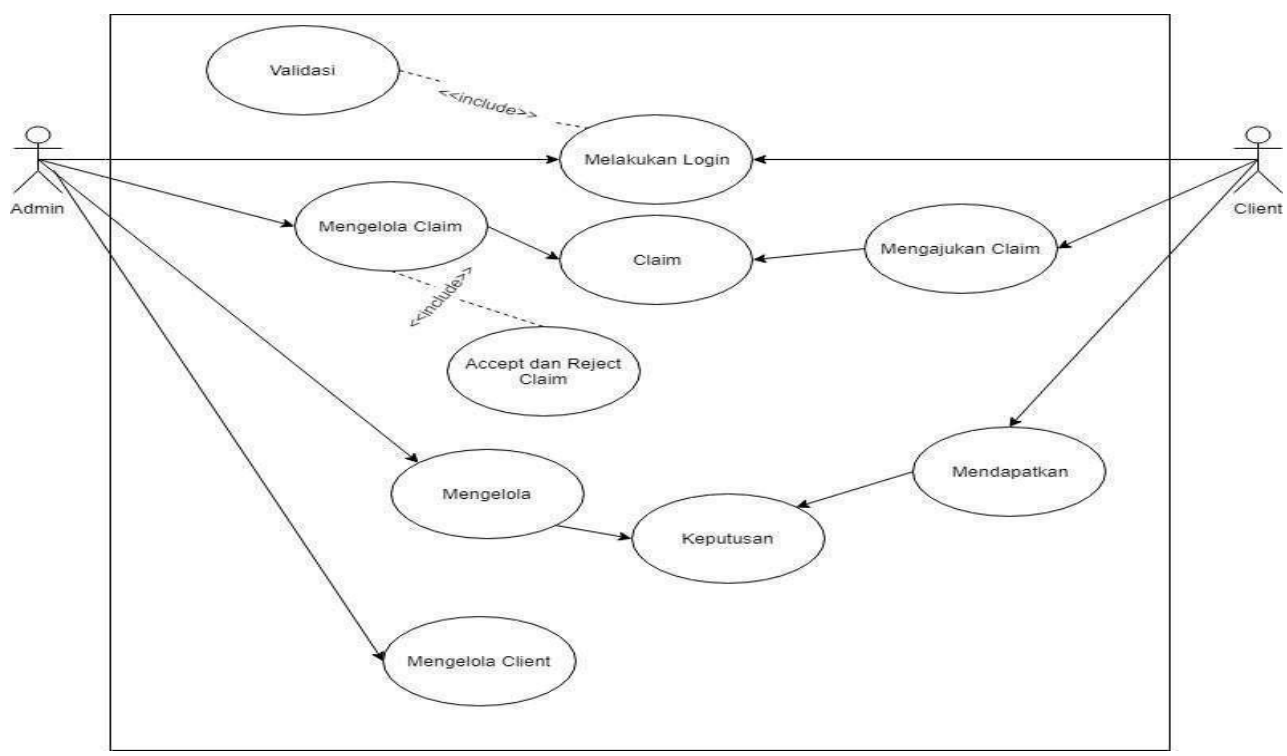

Gambar 4. Use Case Diagram Pengajuan Klaim

Class diagram menggambarkan kelas-kelas yang digunakan dalam aplikasi pengajuan klaim asuransi. Dimana dalam satu kelas client, memiliki beberapa atribut beserta tipe data nya, dan operasi seperti login, input, lihat. Dimana kelas client ber asosiasi dengan kelas klaim, kelas klaim memiliki relasi dengan kelas keputusan, dan kelas admin. Lalu kelas admin ber relasi dengan kelas keputusan

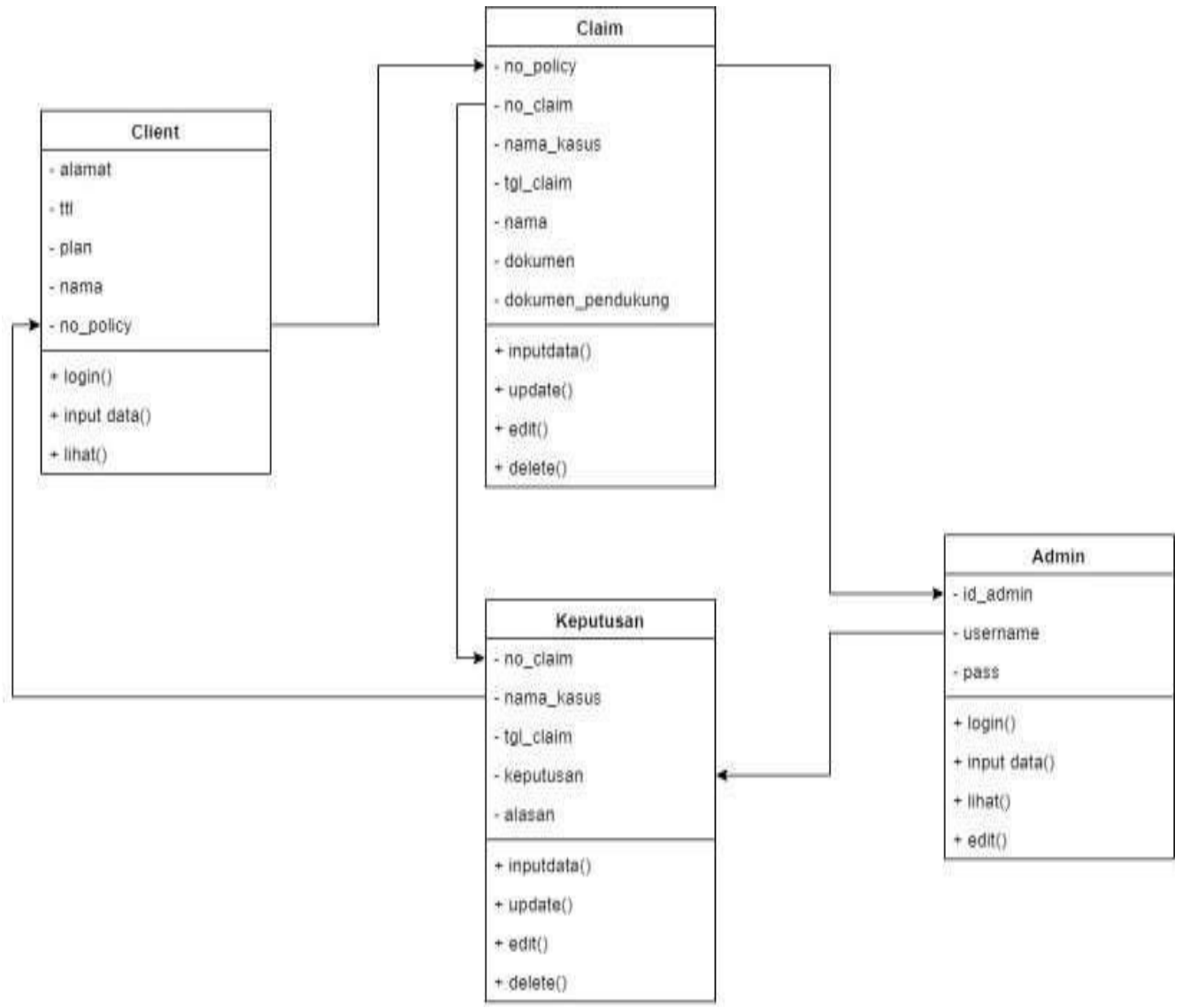

Gambar 5. Class Diagram Pengajuan Klaim 
Terdapat objek client, main, antar muka, form register, database dan register klaim. Dimana klient akan memulian dengan login tampilan main (utama) dan melakukan klaim asuransi di menu form register. Lalu klient akan memasukan nama, alamt, temapt tanggal lahir, plan. Jika sudah selesai bisa klik tombol close.

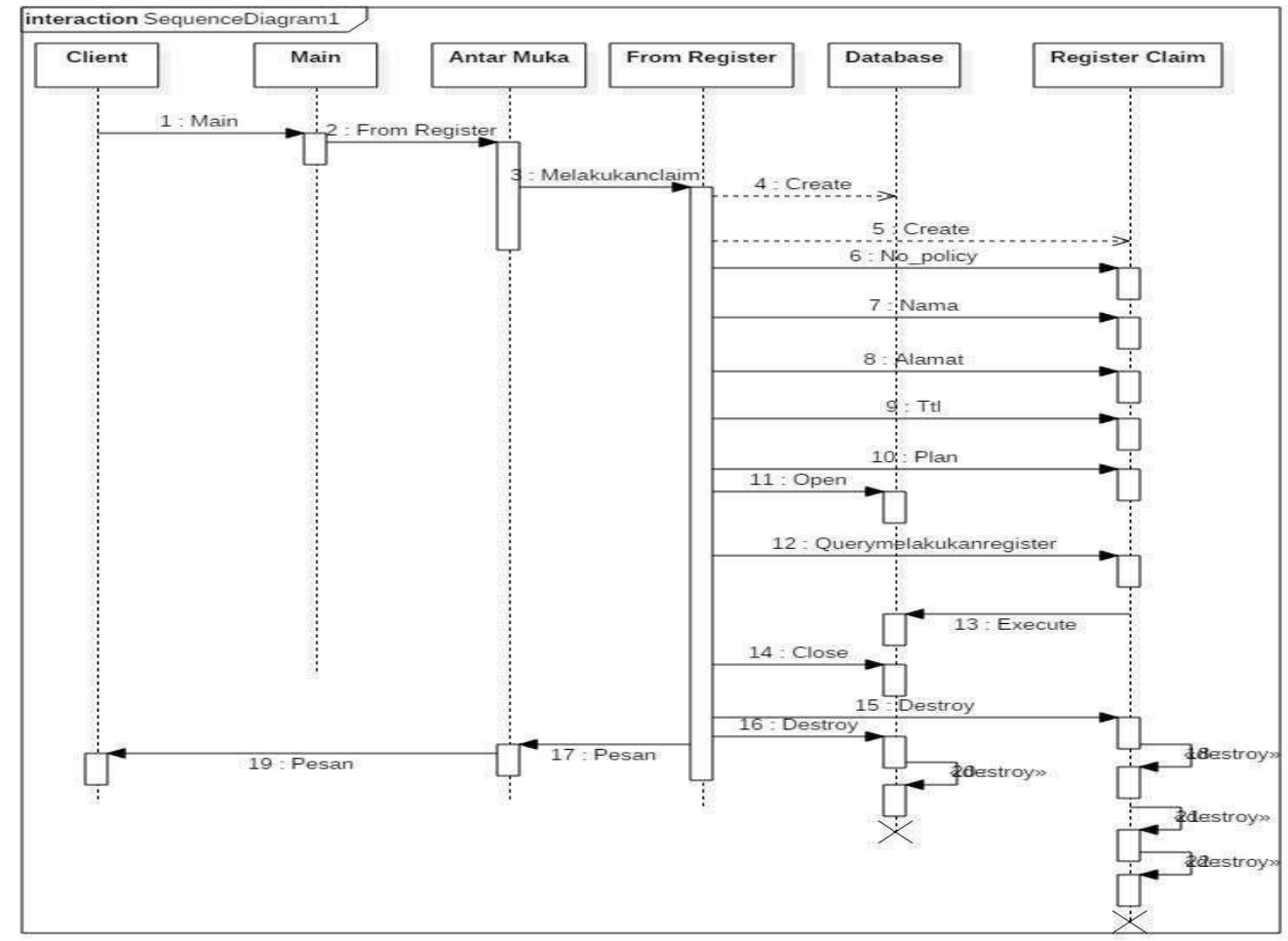

Gambar 6. Sequence Diagram Pengajuan Klaim

\subsection{Rancangan Prototype}

Pada rancangan prototype mengenai gambaran interface dari bahasa pemrograman yang dirancang sebelum melakukan pengkodingan. Maka dari itu penulis membuat rancangan prototype dengan sistem usulan yang dibuat, berikut gambaran rancangan prototype :

a. Interface Menu Login Admin

Admin dapat memulai akses dengan cara masukan username dan password di menu login

SILAHKAN LOGIN

Untik Mendapakan Akses

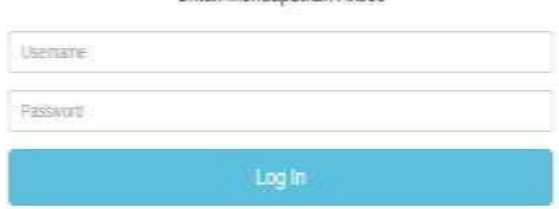

Gambar 7. Menu Login

b. Interface Menu Utama Admin (Home)

Dibawah ini adalah menu utama admin jika admin sukses memasukan username dan password di menu loin. Di menu ini, Admin dapat mengambil keputusan klaim untuk setiap klient di menu Utama admin

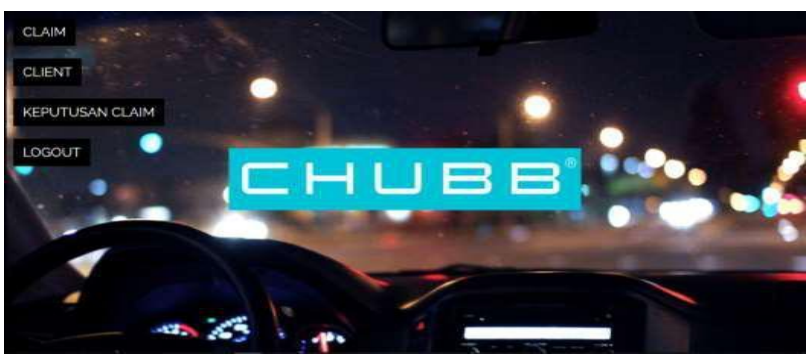

Gambar 8. Menu Utama (Home) Admin 
c. Interface Data Claim Admin

Berikut ini adalah tampilan menu database dari para klient asuransi

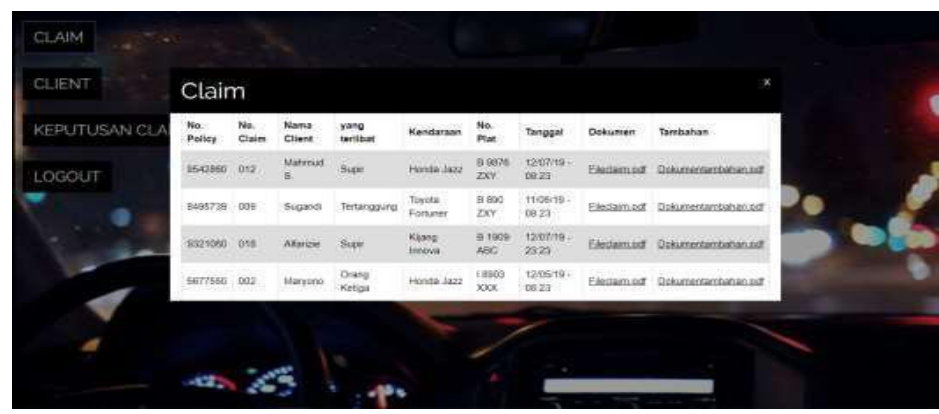

Gambar 9. Data Claim Admin

\section{d. Interface Claim Client}

Berikut ini adalah tampilan menu Interface Klaim klien apabila klient sukses memasukan username dan password di menu login klient.

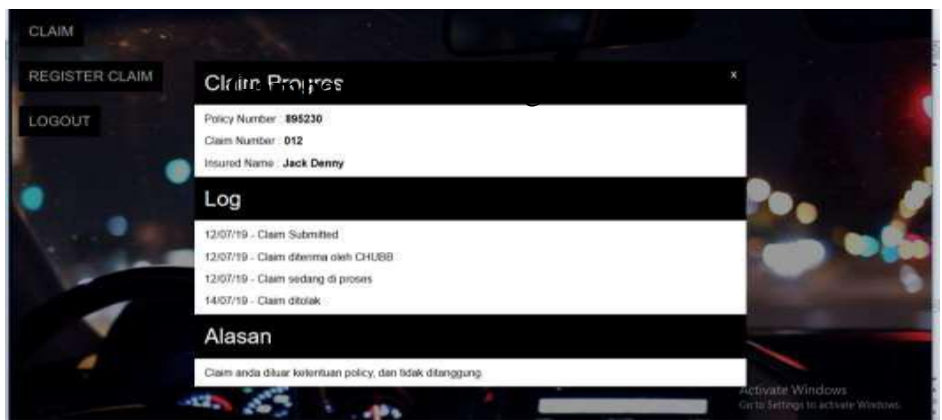

Gambar 10. Tampilan Claim Client

\section{KESIMPULAN}

1. Pengembangan informasi berbasis website ini memudahkan bagi pengakses website karena efektif dan efisien dalam mengakses halaman website.

2. Bagi pengelola website lebih mudah dalam mengelola data dan informasi pada pengajuan klaim kendaraan secara online.

3. Dengan adanya sistem pengajuan klaim kendaraan secara online, kebutuhan user dan pengelola dapat memudahkan cara pendaftaran dan mengelola data dimanapun dan kapanpun tanpa memakan waktu yang lama.

4. Perlu dilakukan pelatihan kepada pengelola yang akan menjadi administrator untuk mengurangi kesalahankesalahan yang tidak diinginkan.

5. Rancangan website ini masih terbilang sederhana, terutama dari segi tampilan dan segi keamanan, ada baiknya untuk tahap pengembangan pada

\section{REFERENCES}

[1] Alloni, K. Y. (2017). ANALISIS DAN DESAIN WEBSITE PROGRAM STUDI ADMINISTRASI BISNIS ( Studi pada Fakultas Ilmu Administrasi Universitas Brawijaya Malang ), 51(2).

[2] Kirana, C., Perkasa, E. B., \& Saputra, R. A. (2018). Rancang Bangun Aplikasi Pengajuan Klaim Asuransi Kendaraan Bermotor Menggunakan Smartphone Berbasis Android, 8-9.

[3] Pendidikan, J., Informatika, T., Teknik, F., \& Negeri, U. (n.d.). Pendidikan dan Pelatihan Profesi Guru (PLPG) TIK Gelombang 14.

[4] Putri, M. E., Ayu, D., \& Wulandari, N. (2016). Sistem Informasi Monitoring Siswa Berbasis Web Dan SMS Gateway Pada SMK Negeri 37 Jakarta, $I I(2), 49-55$.

[5] Sari, K. (2016). Perkembangan Asuransi Kesehatan Swasta di Indonesia Tahun 2012- 2016, 2, 2012-2016.

[6] Suryanto, A. (2016). RANCANG BANGUN SISTEM INFORMASI PENDAFTARAN ARTIS BERBASIS WEB MENGGUNAKAN MODEL WATERFALL (STUDI KASUS : TEAM MANAGEMENT AGENSI). KHATULISTIWA INFORMATIKA, IV(2), 117-126

[7] Shalahuddin, M., \& Sukamto. (2018). Rekayasa perangkat Lunak Terstruktur dan Berorientasi Objek. Bandung: INFORMATIKA. 